1 Bynoe, M. L., Tyrrell, D. A. J., and Walker, 1,603 .

2 Anderson, T. W., Beaton, G. H., and Reid, Dournal, 1972, 107, 503 . fournal, 1972, 107, 503

1, 638 . S., and Wilson, C. W. M., Lancet, 1973 , 1, 638.

et Microb., and Lunbeck, H., Acta Pathologica et Microbiologica Scandinavica, 1955, 37, 493.
Wilson, C. W. M., British Medical fournal, 1971 Wilson,

Loh, H. S., and Wilson, C. W. M., Acta Allergologica, 1969, 24, 367

oster, F. G., Loh, H. S., and Wilson, C. W. M. European fournal of Clinical Pharmacology. In press.

Foster, F. G., Loh, H. S., and Wilson, C. W. M. European fournal of Clinical Pharmacology. In
press. Loh, H. S.,

10 Greene, M., Loh, H. S., and Wilson, C. W. M. European Nutritional Conference, Cambridge,

11 Loh, H. S., and Wilson, C. W. M., European Fournal of Clinical Pharmacology, 1973, 6, in 2 Loh, H. S., Watters, K., Wilson, C. W. M., Irish fournal of Medical Science, 1973, 142, 217.
Barnes, M. J., and Kodicek, E., Vitamins and
Hormones, 1972, 30, 1.

14 Crandon. J. H., Lennihan, R., Mikal, S., and Reif, A. E., Annals of the New York Academy Reif; A. E., Annals of
of Science, 1961, 92, 246.

15 Bartley, W. H., Krebs, A., and O'Brien, J. R. P. Medical Research Council Special Report Series, No. 280. London, H.M.S.O., 1953

16 Reports on Public Health and Medical Subjects, No. 120. London H.M.S.O., 1969.

Korner, W. F., and Weber, F., International $1972,42,528$ 1972 L2, 528.
Medical fournal, 1971, 3, 733. W. M., British

19 Chrystowski, G. A., and Lamden, M. P.. Proceedings of the Society for Experimental Biology and Medicine, 1954, 85. 190 .

20 Briggs, M. H., Davis, P., and Garcia-Webb, P. Lancet, 1973, 2, 201

Loh H. S., and Wilson, C. W. M., fournal of Clinical Pharmacology and New Drugs, 1973, 22 Loh, H. S., and Wilson, C. W. M., Nutrition Reports International, $1971,4,371$. Loh, H. S., European Nutritional Conference. Nutrition. In press.

24 Cox, E. V., Vitamins and Hormones. Advances in research and applications. Vol. 26, p. 635 Loniton. Academic Press, 1968.

25 Loh, H. S., and Wilson, C. W. M., Lancet, 1971, 1. 110

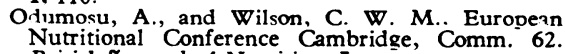
Britich fournal of Nutrition. In press.

Odumosu, A., and Wilson, C. W. M., British 28 Rhead. W. J., and Schranzer, G. 48, 326P. Fmirnal of Vitamin and Nutritional Research, 29 Brioos, M., and Briggs, M., Nature, 1972, 238. 30 McLeroy, V. I., and Schendel, H. E., American 31 Reurnal of Clinical Nutrition, 1973, 26. 191 . Pharmacology. 1972, 5, 116 .
Harris, A. B. Hartley, J., and Moor, A., Lancet, Harris, A. B , Hartley, J., and Moor, A., Lancet,
1973, 2. 201.
Chalonin. H., Mouton, M.. and Ratsimanga, Chalopin. H., Mouton, M.. and Ratsimanga,
A R., World Review of Nutrition and Dietetics,
1966, 6. 165. 1966, 6. 165.
Johancsm. G., Acta Physiologica Scandinavica,
1972. 85. 569. 35 Loh, H. S.. International fournal of Vitamin and

\section{Oral Contraceptives and Myocardial Infarction}

SIR,-With reference to the paper by Drs. Dorothy J. Radford and M. F. Oliver (25 August, p. 428), establishing a relationship between the use of oral contraceotives and the development of illness is clearly important. Some women are at special risk during pregnancy and the risk is sometimes identified during a first or subsequent pregnancy. Further pregnancy may then be avoided by utilization of effective birth control.

Three of the five women aged $31-40$ years reported by Drs. Radford and Oliver who had been taking oral. contraceptives had hypertension (systolic pressure $>100 \mathrm{~mm}$ $\mathrm{Hg}$ ). It is not possible from the paper to identify the probable level of hypertension for these patients before they began taking the pill, though records of previous pregnancy should have been not too difficult to find. The prevalence of coronary thrombosis in the patients taking the pill as represented by, this paper is misleading for the very obvious reason that these patients may well have been using oral contraceptives by reason of their hypertension and were unable to accept other methods of birth control. While it must be very important to draw attention to the findings, it is probably equally important to resist the temptation either to draw conclusions or to make recommendations from a small amount of inadequate information.-I am, etc.,

Department of General Practice,

GARETH LLOYD

University of Manchester

\section{Surgery for Coronary Occlusion}

SIR,-Your leading article (25 August, p. 420) implies that there is a large number of patients who require operation for the relief of intractable cardiac pain. I believe that such patients are, or should be, few and their condition reflects more often inadequacy of medical management than severity of the underlying disease.

Over 10 years ago Dr. J. A. Strong and I, in an article on "Radioiodine for Refractory Cardiac Pain," wrote, "In our experience 'intractable' cardiac pain is an uncommon condition and a diagnosis which need rarely be made if this presumptive conclusion is postponed for a few months. The patient should be told that, if pain continues or increases, more strenuous methods will be indicated, but it is surprising how often pain becomes less 'intractable' if extra attention is paid to every detail of management." This was before the introduction of beta-blocking drugs.

Today many patients are being referred for surgical treatment not having had anything approaching adequate medical management-that is to say, they are still obese, continue to smoke, have not been advised to take their trinitrate prophylactically, and have been given beta-blocking drugs in inadequate dosage. Sufficient attention has not always been paid to emotional factors. In particular, very few have had it explained, in so many words, that exercise, started gently and gradually and progressively increased, should be the cornerstone of management, except in the few with obvious contraindications. Exercise is facilitated by the invariable use of prophylactic trinitrate and a beta-blocking drug in full dosage-that is to say, if necessary and if tolerated, up to at least $480 \mathrm{mg} /$ day of oxprenolol or propranolol. There is little or no risk in beta-blockade if the usual precautions are taken and the patient kept under observation. Exertion should be avoided after meals, in cold air, against the wind, or when emotionally upset, but otherwise pushed to the maximum which can be tolerated without pain, dyspnosa, or undue fatigue. Great confidence is engendered by this positive approach, and capacity for exercise usually improves steadilv.

Bypass grafting carries a significant mortality and morbidity, ${ }^{2} 3$ pain is not always relieved or relief is incomplete, ${ }^{4}$ and as yet there is no evidence that life in survivors will be prolonged. The present time would not seem opportune for the proposed 15centre European trial in which it is hoped that a definitive answer will be given within five years. The trial bristles with difficulties and it is improbable, to say the least, that a definitive answer will be obtained by the present design. In the United States alone, the total number of patients treated by coronary bypass procedures in 1971 was about $25,000^{5}$ and since, except in a few cases, its value is doubtful, ideally it would be best to call a halt and observe the effects of what has been done.

Surely now maximum efforts and resources should be turned to the problems of primary prevention. There are ample grounds for optimism and the time has come greatly to exend work on methodology and feasibility in pilot studies on the necessary screening of the apparently healthy population. Our experience has shown that, far from inducing anxiety or neurosis, as some have feared, confidence is engendered, and there is an increasing demand.-I am, etc.,

RICHARD TURNER

University Department of Medicine

Edinburgh

1 Strong. J. A., and Turner, R. W. D., Quarterly Fournal of Medicine, 1962, 31, 221.
Ross, R. S., and Gorlin, R., Circulation, 1968, 37, suppl. $3,67$.

Heart fournal, 1967, 74, 737 . Koutchoukos. N. T., and Kirklin, J. W., Modern
roncepts of Cardiovascular Disease. 1972, 41, 47. 5 Friedberg, C., Circulation, 1972, 45, 727.

\section{Infection of Peritoneum during Dialysis}

SIR,-Dr D. G. Oreopoulos and Mr. S. Izatt (15 September, p. 592), in commenting on my description of the use of lvsozvme assay for detection of peritonitis during dialysis, do not, I believe, question the usefulness of the assay but whether it distinguiches between "chemical" and infective peritonitis.

I can only sav that a much larger body of experience will have to be accumulated in order to tell whether lysozyme levels are different in the two conditions. In fact, since making a change in the dialysis fluid three years ago we have not recognized "chemical" peritonitis which, as Dr. Orenpoulos and Mr. Izatt point out, should affect grouvs of patients. Our cases of peritonitis have been sporadic, they occur always in patients on weekly maintenance dialysis, and the fact that organisms are not always grown is due firstly to the accented unit policy of giving intrameritoneal antibiotics early and secondly to the fact that acetate fluid is inimical to prolific growth of the organisms. As the figures in my article show, most of our cases respond rapidly to kanamycin; this would not be the case with chemical peritonitis.-I am, etc.,

\section{E. Nigel WARDLE}

University Department of Medicine,

Roval Victoria Infirmary
Newcastle upon Tyne

\section{Anaesthetic Safety Devices}

SIR,-We agree entirely with Dr. R. Parfit's desire (22 September, D. 635) to see oxygen fail-safe devices widely used. We would also accept his five essentials for an ideal safety 
device. We have in fact described a device which meets these requirements in full. ${ }^{1}$

The first part, operated by the pressure of the oxygen supply, comes into operation when the oxygen is turned on and cannot be turned off. When the oxvgen pressure begins to fall the device sounds a warning, then cuts off other vapours or gases and opens the breathing circuit to atmosphere. However, after failure little or no air is drawn in because rebreathing occurs to and from the reservoir bag and this could result in asphyxia. The second part of the device is essential to prevent this rebreathing. The whole device will operate whether the system is semi-open or closed and whether the rebreathing is spontaneous or artificial. The device is manufactured by the British Oxygen Company and the first part is already freely available. However, the manufacturer cannot yet give us a supply date for the complete devices, which have been on order now for more than two years.-We are, etc.,

M. ROSEN Department of Anaesthetics, Cardiff

E. K. HILLARD 1 Rosen, M., and Hillard, E. K., British Fournal of
Anaesthesia, 1971, 43, 103.

\section{Social Workers in Hospitals}

SIR,-I wor'd like to comment on the letter from Dr. P. E. Baldry (15 September, p. 589), which roncerned mv article on "Social Workers in Hospitals" (25 Auoust, p. 443). The writer of that letter made several questionable points, the most fundamental of which was that social workers have no special expertise which would enable them to help the patient in areas of psychosocial functioning. He argued that doctors and nurses are just as well equipped as the social worker to undertake this kind of helping work. I would contend, however, that a psychosocial orientation to the patient must be based on knowledge, together with an understanding of how to apoly this sensitively to each person's particular situation.

Dr. Baldry states that he does not want social workers interfering in the "delicate interpersonal relationships between doctor, ward sister, and patient." I would refer him to Dr. Ann Cartwright's research on this matter. She concludes a chapter on communication between patients and doctors by saying, "The present arrangements do not encourage a personal relationship between patients and hospital doctors. If communications are to be improved some doctors need to be more approachable people, less like inaccessible Gods." To often the patient does not have any relationship at all with the doctor. The development of such a relationship must be an ongoing concern and takes a great deal of time and patience. Do most doctors have the time, knowledge, understanding of rational and irrational forces and fears to have such a flexible and developing relationship with the patient? I very much doubt it.

Dr. Baldry also asserts that social workers would probably not become quite so out of hand if doctors "laid down sufficiently clear guidelines as to what is reauired from them," as they do for other ancillary workers. Firstly, social workers do not stand in the same relation to the hospital endeavour as radiographers, physiotherapists, etc., and to put all such workers under the same umbrella shows a distinct lack of subtlety in understanding their different roles in relation to doctor and patient. Secondly it does not seem to occur to Dr. Baldry that discussion between social workers and doctors on the basis of exchange of knowledge and ideas between colleagues might yield more fruitful results for all concerned.-I am, etc.,

\section{Baadford}

Carole R. Smith

1 Cartwright, A.. Human Relations and Ho-pital
Care, p. 100. London, Routledge and Kegan
Paul, 1969.

\section{Excretion Urography in Acute Renal Failure}

SIR,-We note with interest the letter from Dr. J. M. Vandenbroucke and his colleagues (4 August, p. 291) commenting on our paper on excretion urography in acute nonobstructive renal failure ( 9 June, p. 575) and reporting their own experience. Like them, we are puzzled by the considerable difference between our results. We find it difficult to attribute this solely to the number of patients studied because of the large difference between the two series in the proportion of patients with "acute tubular necrosis" showing an early dense persisting nephrogram.

While we recognize that it is not possible ro give extensive details in a letter we would like to have known the clinical status of the patients at the time of excretion urography. Thus if the patients were volumedepleted or hypotensive with consequent renal circulatory failure the nephrographic pattern could well be affected.'

We also note that Dr. Vandenbroucke and his colleagues employed the methylglucamine salt of iothalamate while we have used exclusively the sodium salt of diatrizoate. While we are still not certain of the precise mechanism of the development of the nephrogram in "acute tubular necrosis" there are theoretical reasons for believing that the sodium salt might give a better nephrogram than the methylglucamine salt because of better concentration, possibly at the proximal tubular level. ${ }^{2}$ We are not aware of any study which has compared the sodium salt with the methylglucamine salt in this clinical situation.

We agree that considerable attention must be paid to the radiographic technique, and failure to obtain comparable exposures largely nullifies the value of the investigation. We do not acceot, however, that it is too difficult to obtain comoarable exposures and would re-emphasize that if these are not achieved the results of the investigation must be interpreted with extreme caution.

Finally, we cannot accept the statement that "unfortunately, the nephrographic patterns are not sufficiently distinctive to lead to an accurate diagnosis in nonobstructive acute renal failure." Our main conclusion was that if an early dense persisting nephrogram is observed in natients with acute renal failure, this indicates uncomplicated "acute tubular necrosis" or surpourative pyelonephritis. Dr. Vandenbroucke's results do not refute this. This observation alone is of value to the clinician. If this nephrographic pattern is not found we would submit that the diagnosis of "acute tubular necrosis" should be reconsidered and the need for further investigation -for example, renal biopsy-be assessed. In addition to their clinical value, such studies may yet lead to more accurate definition of the pathophysiology of the ill-defined syndrome of "acute tubular necrosis."-We are, etc.,

W. R. Cattell

I. KELSEY FRY

St. Bartholomew's/St. Leonard's Regional Rena Unit and Departments of Radiology, St. Bartholomew's and St. Leonard's Hospitals,

1 Frv, I. K., and Cattell, W. R., British Medical Bulletin, 1972, 28, 227.
2 Cattell, W. R., Investigative Radiology, 1970, 5,
473.

Psychiatric Aspects of Sterilization

SiR,-The recommendations made by Dr. Myre Sim and others (28 July, p. 220) deserve the attention of family olanning authorities and psychiatrists in developing countries, where female sterilization by tubal ligation is practised on a much wider scale than in western Europe. In the subcontinent of India an increasing number of tubal ligations are done each year. This oneration, contrary to what Dr. Sim and his colleagues recommend, is carried out at childbirth or during the neonatal period.

In India during the last decade a Government-sponsored campaign with financial inducements resulted in indiscriminate male sterilization without adequate screening and caused psychiatric sequelae in a substantial proportion of those operated upon. Similarly, intrauterine loop contraception was introduced on a wide scale in the villages without proper selection and with equally poor explanation of its side effects. Sawhney et al. ${ }^{1}$ reoorted that $21.6 \%$ of the population who underwent vasectomy or tubal ligation or were finted with an I.U.C.D. suffered from psychiatric sequelae.

In a follow-up of 82 subjects who underwent vasectomy for family planning Wig et al. ${ }^{2}$ reported that $36.5 \%$ of them complained of symotoms attributable to the operation. "Post-vasectomy syndrome" is a common referral in many psvchiatric and urological clinics in India. Poor selection and inadequate exolanation about the possible side effects and long-term consequences of family mlanning procedures have resulted in the spread, mainly by word of mouth, of exaggerated and at times fanciful renorts of side effects among the unsophisticated population of rural India.

It is now abundantly clear that whatever method of contracention is advised the physician must not only be aware of the psychiatric sequelae of the various procedures but also take into account his patient's nremorbid personality, social background (to recognize cultural factors), and religious beliefs, and most of all appreciate his client's emotional and intellectual capacity to cope with the contracentive method recommended.

In developing countries population control is now a matter of the utmost concern to politicians and administrators alike. Considerable pressure is being brought uoon physicians to implement the Government's 